\title{
AGAMA DAN POLITIK DI KALIMANTAN SELATAN
}

\author{
Mirhan AM \\ Fakultas Ushuluddin dan Humaniora \\ IAIN Antasari Banjarmasin \\ Diterima tanggal 3 Juli 2016 / Disetujui tanggal 9 Mei 2016
}

\begin{abstract}
Politics cannot be separated from religion. The combination between them have uttered the political religious thoughts in order to create a harmonious and peaceful life in the nation. Religious beliefs can impact laws in common, such as the thought of sodomy and incest is a sin, so it become illegal in national laws. While religion gives legitimacy to the government to act. Religion is deeply embedded in the lives of people in industrial societies and non-industrial, so its presence may not be felt in the political sphere. But it is considered or not, religion has a role to form a political power. In Islam, Medina Charter contained aspects of life either it comes to diversity as well as a matter of policy set to pluralistic society, cannot be regarded as a statement of the establishment of the Islamic State. Yet, in this contemporary era, the teachings of Islam were able implied in issues of national state and life of the community.
\end{abstract}

Kata kunci: Agama, Piagam Madinah, politik, ajaran-ajaran Islam.

\section{Pendahuluan}

Pembicaraan tentang agama dan politik sebenarnya sudah lama terjadi dalam sejarah Islam, sepeninggal Nabi Muhammad Saw. perbincangan siapa yang berhak menggantikan Nabi yang pada waktu itu Nabi telah dikenal sebagai pemimpin agama dan pemimpin negara di Madinah. Ketika para sahabat dihadapkan pada persoalan ini, saat itu agama dan politik menjadi hal yang dipertentangkan.

Di kalangan umat Islam terdapat dua arus pemikiran yang mendasar dalam merespons tentang agama dan politik. Pertama, pemikiran yang menyatakan bahwa ajaran Islam adalah ajaran yang bersifat universal. Islam dianggap sesuatu yang lebih dari sekedar sebuah agama, tapi juga mencakup semua aspek kehidupan termasuk di dalamnya adalah Islam adalah al-Islam dînun wa daulah. Kedua, ada yang berpendapat bahwa tidak ada bukti jelas mengenai ajaran Islam yang berdasarkan al-Qur'an dan Sunnah Nabi Muhammad. Saw. mengharuskan orang Islam mendirikan negara Islam. Pengalaman politik Nabi Muhammad Saw. di Madinah yang sangat terkenal dengan adanya undang-undang yang mengatur tentang kehidupan umat pada saat itu, yakni dengan adanya Piagam Madinah.

Piagam Madinah di dalamnya memuat aspek-aspek kehidupan, baik menyangkut soal keberagamaan maupun soal kebijakan politik mengatur masyarakat yang plural, tidak bisa dianggap sebagai pernyataan berdirinya Negara Islam. Akan tetapi sekarang bagaimana ajaran-ajaran Islam mampu terimplikasikan dalam segala persoalan kehidupan masyarakat berbangsa dan bernegara. Dalam tulisan ini, penulis mencoba mengemukakan tentang agama dan politik di Kalimantan Selatan dengan pembahasan pengertian agama dan politik, hubungan agama dan politik, kenyataan sosiologis agama dan politik di Kalimantan Selatan dan hubungan agama dan politik. 


\section{Pengertian Agama Dan Politik}

\section{A. Pengertian Agama}

Agama berasal dari bahasa Sansekerta yang terdiri dari dua suku kata yaitu a yang berarti tidak dan gama berarti kacau, sehingga agama artinya "tidak kacau", dengan pengertian terdapat ketentraman dalam berpikir sesuai dengan pengetahuan dan kepercayaan yang mendasari kelakuan. ${ }^{1}$ Agama adalah sistem, prinsip kepercayaan kepada Tuhan (Dewa) dengan ajaran kebaktian dan kewajiban-kewajiban yang bertalian dengan kepercayaan itu. ${ }^{2} \mathrm{Hal}$ itu mengandung pengertian bahwa agama adalah suatu peraturan yang mengatur kehidupan manusia agar tidak kacau.

Agama atau religion dalam bahasa Inggris, berasal dari bahasa latin religion yang berarti agama, kesucian, kesalehan, ketelitian batin; religere yang berarti mengikatkan kembali, pengikatan bersama. Beberapa arti agama yang terungkap dalam Webster's Dictionary adalah sebagai berikut:

1. Percaya kepada Tuhan atau kekuatan superhuman atau kekuatan yang di atas disembah sebagai pencipta dan pemelihara alam semesta;

2. Ekspresi dari kepercayaan di atas berupa amal ibadah;

3. Suatu sistem kepercayaan, peribadatan, amal dan sebagainya yang sering melibatkan kode etik dan filsafat tertentu, misalnya tercermin dalam ungkapan: agama Kristen, agama Budha dan sebagainya;

4. Suatu sistem kepercayaan, pengalaman dan nilai etika sistem kepercayaan, pengalaman dan nilai etika dan sebagainya, yang menyerupai suatu sistem.

5. Suatu keadaan jiwa atau cara hidup yang mencerminkan kecintaan atau kepercayaan terhadap Tuhan; kehendak dari prilakunya sesuai dengan aturan Tuhan;

6. Suatu objek yang dianggap berharga dan menjadi tujuan hidupnya;

7. Amal ibadah yang tampak;

8. Aturan agama atau lingkungan agama. ${ }^{3}$

Cicero, secara sederhana mendefinisikan agama sebagai "the pious worship of god"4 (beribadat dengan tawakkal kepada Tuhan). Menurut sebahagian ahli Sosiologi adalah: Religion is collective expression of human value (agama adalah ekspresi kolektif nilai-nilai manusiawi).

Memang diakui dalam memberikan definisi agama tidak ada definisi yang berlaku atau diakui secara umum, tetapi masing-masing memberikan batasannya sesuai dengan pandangan mereka. Namun dapat kita pahami bahwa agama sangat terkait dengan masalah ketuhanan, peribadatan dan etika manusia. Agama dilahirkan berupa tindakan-tindakan manusia dan masyarakat yang mengandung nilai positif. Dengan demikian ahli Sosiologi memandang bahwa agama dapat mempengaruhi masyarakat juga sebaliknya masyarakat dapat mempengaruhi agama, pengaruh timbal balik dan saling berkaitan interaksi dan interrelasi, antara keduanya yakni agama dan masyarakat, masyarakat dan agama. ${ }^{6}$

Menurut inti maknanya yang khusus, kata agama dapat disamakan dengan kata religion dalam bahasa Inggris, religie dalam bahasa Belanda - keduanya berasal dari bahasa latin religio, dari akar kata

1Zulfi Mubaraq, Sosiologi Agama (Malang: UIN-Maliki Press, 2010), cet. I, 2.

2 Departemen Pendidikan dan Kebudayaan, Kamus Besar Babasa Indonesia (Jakarta: Balai Pustaka, 1995), 10.

${ }^{3}$ Noah Webster and Jean L. McKehnie, Webster's New Universal Unabridged Dictionary (New York: New World Dictionary/Simon and Schuser, 1979), 1527.

${ }^{4}$ William M. Newman, The Social Meaning of Religion (Chicago: Rand Mcnally Collge Publishing Company, 1974), 17. 
religere yang berarti mengikat. ${ }^{7}$ Dalam bahasa Arab, agama dikenal dengan kata al-din dan al-millah. Kata al-din sendiri mengandung berbagai arti. Ia dapat diartikan al-mu'taqad (kepercayaan), al-taubîd (tauhid), al-sulthân (kekuasaan), al-dînah (kebiasaan), ${ }^{8}$ dan lain-lain. Sedangkan pengertian al-dìn yang berarti agama adalah nama yang bersifat umum. Artinya, tidak ditujukan kepada salah satu agama; ia adalah nama untuk setiap kepercayaan yang ada di dunia ini. Adapun agama dalam pengertian sosiologi adalah gejala sosial yang umum dan dimiliki oleh seluruh masyarakat yang ada di dunia ini, tanpa kecuali. Ia merupakan salah satu aspek dalam kehidupan sosial dan bagian dari sistem sosial suatu masyarakat.'

Menurut Harun Nasution agama diberi definisi sebagai berikut

1. Pengakuan terhadap adanya hubungan manusia dengan kekuatan gaib yang harus dipatuhi.

2. Pengakuan terhadap adanya kekuatan gaib yang menguasai manusia.

3. Mengikatkan diri pada suatu bentuk hidup yang mengandung pengakuan pada suatu sumber yang berada di luar diri manusia dan yang mempengaruhi perbuatan-perbuatan manusia.

4. Kepercayaan pada suatu kekuatan gaib yang menimbulkan cara hidup tertentu.

5. Suatu sistem tingkah laku (code of conduct) yang berasal dari sesuatu kekuatan gaib.

6. Pengakuan terhadap adanya kewajiban-kewajiban yang diyakini bersumber pada suatu kekuatan gaib.

7. Pemujaan terhadap kekuatan gaib yang timbul dari perasaan lemah dan perasaan takut terhadap kekuatan misterius yang terdapat dalam alam sekitar manusia.

8. Ajaran-ajaran yang diwahyukan Tuhan kepada manusia melalui seorang Rasul. ${ }^{10}$

Dilihat dari sudut kategori pemahaman manusia, agama memiliki dua segi yang membedakan dalam perwujudannya, yaitu sebagai berikut.

1. Segi kejiwaan (psychological state), yaitu suatu kondisi subjektif atau kondisi dalam jiwa manusia, berkenaan dengan apa yang dirasakan oleh penganut agama. kondisi inilah yang biasa disebut kondisi agama, yaitu kondisi patuh dan taat kepada yang disembah. Emosi ${ }^{11}$ keagamaan seperti itu merupakan gejala individual yang dimiliki oleh setiap penganut agama yang membuat dirinya merasa sebagai makhluk Tuhan. Dimensi religiusitas merupakan inti dari keberagamaan. Inilah yang membangkitkan solidaritas seagama, menumbuhkan kesadaran beragama, dan menjadikan seseorang menjadi orang yang saleh dan takwa.

2. Segi objektif (objective state), yaitu segi luar yang disebut juga kejadian objektif, dimensi empiris dari agama. keadaan ini muncul ketika agam dinyatakan oleh penganutnya dalam berbagai ekspresi, baik ekspresi teologis, ritual maupun persekutuan. Segi objektif inilah yang bisa dipelajari apa adanya dan dengan demikian bisa dipelajari dengan menggunakan metode ilmu sosial. Segi kedua ini mencakup adat istiadat, upacara keagamaan, bangunan, tempat-tempat peribadatan, cerita yang dikisahkan, kepercayaan, dan prinsip-prinsip yang dianut oleh suatu masyarakat. ${ }^{12}$ Dalam hal ini termasuk di dalamnya adalah persoalan-persoalan yang menyangkut tata kepemerintahan, kepemimpinan, kebijakan, kekuasaan yang sering disebut dengan istilah politik

7Dadang Kahmad, Sosiologi Agama (Bandung: Remaja Rosdakarya, 2000), Cet. I, h. 13.

${ }^{8}$ Ahmad Warson Munawwir, Kamus al-Munawwir Arab-Indonesia Terlengkap (Surabaya: Pustaka Progressif, 1997), Cet. II, 437.

${ }^{9}$ Dadang Kahmad, Sosiologi Agama, 13-14.

${ }^{10}$ Harun Nasution, Islam Ditinjau dari Berbagai Aspeknya, Jilid I (Jakarta: Universitas Indonesia Press, 1985), 10.

${ }^{11}$ Emosi dalam bahasa Arab juga dikenal dengan istilah al-syu'ûr yaitu perasaan yang diketahui atau disadari, lihat: Abdul Mujib, Kepribadian dalam Psikologi Islam (Jakarta: PT RajaGrafindo Persada, 2007), 86.

${ }^{12}$ Dadang Kahmad, Sosiologi Agama, 14. 
Memang diakui dalam memberikan definisi agama tidak ada definisi yang berlaku atau diakui secara umum, tetapi masing-masing memberikan batasannya sesuai dengan pandangan mereka. Namun dapat kita pahami bahwa agama sangat terkait dengan masalah ketuhanan, peribadatan dan etika manusia. Agama dilahirkan berupa tindakan-tindakan manusia dan masyarakat yang mengandung nilai positif. Dengan demikian ahli Sosiologi memandang bahwa agama dapat mempengaruhi masyarakat juga sebaliknya masyarakat dapat mempengaruhi agama, pengaruh timbal balik dan saling berkaitan interaksi dan interrelasi), antara keduanya yakni agama dan masyarakat, masyarakat dan agama

\section{B. Pengertian Politik}

Politik adalah pengetahuan mengenai ketatanegaraan atau kenegaraan seperti tentang sistem pemerintahan, dasar pemerintahan. Segala urusan dan tindakan (kebijakan, siasat, dsb) mengenai pemerintahan negara atau terhadap negara lain. Cara bertindak dalam menghadapi atau menangani suatu masalah kebijaksanaan. ${ }^{13}$

Istilah politik berasal dari kata polis (bahasa Yunani) yang artinya negara kota. Dari kata polis dihasilkan kata-kata, seperti:

1. Politeia artinya segala hal ihwal mengenai negara.

2. Polites artinya warga negara.

3. Politikus artinya ahli negara atau orang yang paham tentang negara atau negarawan.

4. Politicia artinya pemerintahan negara.

Secara umum dapat dikatakan bahwa politik adalah kegiatan dalam suatu sistem politik atau negara yang menyangkut proses penentuan tujuan dari sistem tersebut dan bagaimana melaksanakan tujuannya. Negara adalah suatu organisasi dalam suatu wilayah yang mempunyai kekuasaan tertinggi yang sah dan ditaati oleh rakyatnya. Kekuasaan yaitu kemampuan sesorang atau suatu kelompok untuk mempengaruhi tingkah laku orang atau kelompok sesuai dengan keinginan dari pelaku. ${ }^{14}$

Aristoteles (384-322 SM) dapat dianggap sebagai orang pertama yang memperkenalkan kata politik melalui pengamatannya tentang manusia yang ia sebut zoon politikon. Dengan istilah itu ia ingin menjelaskan bahwa hakikat kehidupan sosial adalah politik dan interaksi antara dua orang atau lebih sudah pasti akan melibatkan hubungan politik. Aristoteles melihat politik sebagai kecenderungan alami dan tidak dapat dihindari manusia, misalnya ketika manusia mencoba untuk menentukan posisinya dalam kehidupan bermasyarakat, ketika manusia berusaha mencapai kesejahteraan, dan ketika manusia berupaya memengaruhi orang lain agar pandangannya dapat diterima. Sehingga dapat disimpulkan bahwa politik adalah bermacam-macam kegiatan dalam suatu sistem (negara atau kepemerintahan) yang menyangkut proses menentukan dan melaksanakan tujuan dari sistem tersebut. Menyangkut keputusan (decision making), kebijakan-kebijakan umum (public policies), yang menyangkut pengaturan dan pembagian (distribution) atau alokasi (allocation) dari sumber-sumber (resources) yang ada. ${ }^{15}$

Menurut Imam Suprayogo berbicara tentang politik, pengertiannya sering dikaitkan dengan masalah pemerintahan, kekuasaan, konflik, partai politik atau upaya-upaya yang ditempuh perseorangan maupun kelompok untuk memperjuangkan kepentingan warga negara pada umumnya.

\footnotetext{
${ }^{13}$ Departemen Pendidikan dan Kebudayaan, Kamus Besar Bahasa Indonesia, 780.

14 http:/ / akank-sutha.blogspot.co.id/2012/04/hubungan-politik-dan-agama.html, diakses tanggal 1 November

15http:/ /akank-sutha.blogspot.co.id/2012/04/hubungan-politik-dan-agama.html, diakses tanggal 1 November
}

2015. 
Setidaknya terdapat lima pandangan pemahaman tentang politik. Pertama, politik ialah usaha-usaha yang ditempuh warga negara untuk membicarakan dan mewujudkan kebaikan bersama. Kedua, adalah segala hal yang berkaitan dengan penyelenggaraan negara dan pemerintahan. Ketiga, politik adalah segala kegiatan untuk mencari dan mempertahankan kekuasaan dalam masyarakat. Keempat, politik adalah kegiatan yang berkaitan dengan perumusan dan pelaksanaan kebijakan umum. Kelima, politik adalah mencari dan atau mempertahankan sumber-sumber yang dianggap penting. ${ }^{16}$

\section{Agama dan Politik di Kalimantan Selatan}

Kenyataan sosiologis bahwa keterkaitan antara agama dan politik di Kalimantan Selatan sudah terjadi sejak zaman kerajaan. Seorang raja dimotivasi oleh semangat keagamaan. Ajaran agama dijadikan sebagai nilai dasar moralitas perjuangan dalam memimpin rakyat. Haram baginya untuk melanggar amanah yang diajarkan agamanya. Ajaran agama menjadi petunjuk utama dalam bersikap, berbuat, dan bertindak, sehingga apapun yang dilakukannya selalu didasarkan pada moralitas ajaran agama. Motivasi agamalah yang telah membawa Pangeran Antasari berjuang bersama rakyatnya dan berani menyatakan "Haram manyarah, waja sampai kaputing". Kemudian perhatikan pula bagaimana Sultan Adam al-Wadsiq billah memimpin rakyat dengan moralitas agama. Sultan Adam al-Wadsiq billah adalah seorang yang memahami ajaran agama dengan baik, seorang Sultan yang dekat dengan ulama dan rakyat, selalu berupaya untuk mendapatkan nasihat dan hikmah untuk kebaikan hidup rakyat, dan termasuk dalam tataran kekuasaan pemerintah sejak dulu, sekarang dan akan datang, ulama sebagai pemimpin nonformal menduduki peran penting sehingga kata dan fatwa mereka dijadikan pegangan dalam berbuat. ${ }^{17}$

Salah satu contoh keterkaitan agama dengan politik di Kalimantan Selatan ketika K. H. Muhammad Zaini Abdul Ghani masih hidup. Tercatat banyak pejabat, politikus, dan tokoh masyarakat yang datang bertamu ke kediamannya dengan berbagai maksud dan kepentingan. Sudah tidak terhitung banyaknya tamu yang berkunjung, mulai dari artis, pejabat negara, pejabat lokal, petinggi militer, hingga para menteri, presiden dan wakil presiden. Dari luar negeri seperti Yaman, Hadramaut, Malaysia, Brunei Darussalam. Di kalangan militer, terutama yang bertugas di Pangdam VI Tanjungpura selalu bersilaturrahim kepadanya. Tercatatlah nama Mayor Jenderal TNI Namuri Anoem, Mayjen TNI Z.A. Maulani, Mayjen TNI Muchdi Purwo Pranjono, Mayjen TNI Yacop Dasto, Mayjen TNI Sang Nyoman Suwisma, Mayjen TNI Zainuri Hasyim, Mayjen TNI Joko Besariman, Mayjen TNI Hadi Waluyo, Mayjen TNI Herry Cahyana, dan lain-lain. Pejabat militer lainnya tercatat Kepala Staf Angkatan Darat TNI (KASAD), Jenderal TNI Hartono, Kasospol TNI Letnan Jenderal TNI Syarwan Hamid, Danpuspom TNI Djasrie Marien dan lain-lain. Para menteri seperti; Ali Said SH, Harmoko, Hartono, Wardiman Djojonegoro, Marzuki Usman, Muslimin Nasution, Fahmi Idris, Tholhah Hasan, Said Agil Husein Al-Munawwar, Wiranto, Jaksa Agung MA Rachman, Alwi Shihab, Syamsul Mu'arif, Ali Marwan Hanan, Sri Sultan Hamengkubowono X, Akbar Tandjung, H. Tarmizi Taher, Siti Hardiyanti Indra Rukmana, Ismail Hasan Metareum. ${ }^{18}$ Presiden Megawati Soekarnoputri, Presiden Abdurrahman Wahid (Gus Dur) dan Wakil Presiden Hamzah Haz. Hamzah Haz bahkan datang bertakziah ketika K.H. Muhammad Zaini Abdul Ghani berpulang ke rahmatullah, larut dalam duka bersama masyarakat Kalimantan Selatan dalam upacara pemakaman. ${ }^{19}$

16Imam Suprayogo, Kyai dan Politik. Membaca Citra Politik Kyai (Malang: UIN Malang Press, 2009), 44.

${ }^{17 Z u l f a ~ J a m a l i e, ~ " S u l t a n ~ B a n j a r ~ y a n g ~ M e n c i n t a i ~ d a n ~ D i c i n t a i ", ~ d a l a m ~ B e r k e l a n a ~ M e n c a r i ~ S u l t a n ~ B a n u a ~ B a n j a r, ~}$ (Banjarmasin: Pustaka Banua), 253-254.

${ }^{18}$ Ahmad Rosyadi, Bertamu ke Sekumpul (Yogyakarta: PT. LKiS Pelangi Aksara, 2004), Cet. III, 23-24.

${ }^{19}$ Redaktur, "Belum Ada Tandingannya", Banjarmasin Post, Kamis, 11 Agustus 2005. 
Dari Kalangan kepolisian, baik yang bertugas di Kalimantan Selatan, Kapolda atau Kapolres dan petinggi Polri di Jakarta, Brigjen Soni Harsono, Brigjen Pol H. Mudji Hardjadi, Brigjen Pol H. Basyir Ahmad Barmawi, Brigjen Pol Sumantyawan HS, Kapolri Da'i Bachtiar juga sering datang bersilaturrahim ke Sekumpul. Di kalangan figur publik semisal Arie Sigit (cucu Presiden Soeharto), Ais Anantama Said (putra Ali Said SH), Isfan Fajar Satyo (putra Wapres Try Sutrisno), K.H. Zainuddin MZ, K.H. Muhammad Syukron Makmun, K.H. Hasyim Muzadi, K.H. Cecep Saipuddin, K.H. Muhammad Arifin Ilham, K.H. Abdullah Gymnastiar (Aa Gym) juga menyempatkan diri untuk mampir Sekumpul. ${ }^{20}$

Mereka datang untuk bersilaturrahim, meminta petuah/nasehat dan berkonsultasi masalah keagamaan dan bahkan beberapa tamu meminta untuk dijadikan anak angkat, sehingga memanggil K.H . Muhammad Zaini Abdul Ghani dengan panggilan Abah Guru ${ }^{21}$ atau hanya Abah saja. ${ }^{22}$

Ribuan tamu yang datang silih berganti, dari kalangan pejabat, tokoh agama, pemimpin politik yang notabene adalah mereka sebagai pengurus atau pimpinan politik di level nasional dan lokal di Provinsi Kalimantan Selatan. Para politisi ini ingin memperlihatkan bahwa mereka selalu mendekatkan diri dengan figur ulama dan ingin menunjukkan terutama kepada jamaah pengajian (ketika sedang diadakan pengajian) bahwa mereka adalah orang-orang yang selalu memperhatikan persoalan yang berkaitan dengan agama terutama dengan kepentingan politiknya.

Ada penggalan sebuah syair yang berbunyi:

Pengajian Sekumpul membawa berkah

Akhirat berkah dunia berkah

Ojek dan taksi becak pun berkah

Inilah majlis pembawa rahmah

Beliau ulama bukan umara

Bahkan umara datang padanya

Duduk bersimpuh dengan ta'limnya

Bersih politik melulu agama

Beliau terkenal karismatiknya

Pejabat Negara bahkan Presidennya

Semuanya datang minta do'anya

Ngambil berkahnya dengan nasihatnya ${ }^{23}$

Menurut H. Amidhan, ketua MUI pusat, bahwa Guru Sekumpul adalah seorang ulama karismatik yang selalu menjembatani hubungan pemerintah dengan rakyat. ${ }^{24}$ Menjembatani hubungan

${ }^{20}$ Ahmad Rosyadi, Bertamu ke Sekumpul, 24-25.

${ }^{21}$ Bahasa Banjar untuk panggilan, sama maksudnya dengan bapak atau ayah.

${ }^{22}$ Ahmad Rosyadi, Bertamu ke Sekumpul, 28.

${ }^{23}$ Abdul Hakim, Syair-Syair yang Berisi Pujian kepada Al-Mukarraom Al'Alim Al'Allamah Syekh Muhammad Zaini Sekumpul Martapura, (Martapura: Prc. Putra Sahara.Comp, t.th.), 1 - 13.

${ }^{24}$ Redaktur, "Kesan Mereka Terhadap Guru Sekumpul", Banjarmasin Post, Kamis, 11 Agustus 2005. 
pemerintah dengan masyarakat ini jelas ada kaitannya dengan kekuasaan atau dunia politik. Nasehat K.H. Muhammad Zaini Abdul Ghani sebagai ulama selalu diminta. Hal ini menunjukkan betapa pentingnya hubungan agama (ulama) dengan politik. Dunia politik diambil dari pengertian politik sebagai usaha-usaha yang ditempuh warga negara untuk membicarakan dan mewujudkan kebaikan bersama.

K.H. Muhammad Zaini Abdul Ghani bisa saja dipandang memiliki peran dalam politik, dalam pengertian politik yang tidak berpihak. Hal ini sering dilakukan oleh para pemimpin politik yang datang bertamu dan bersilaturrahim, atau mereka yang tengah memegang kekuasaan atau akan mencari kekuasaan. Mereka datang ke tempat K.H. Muhammad Zaini Abdul Ghani, kemudian disiarkan oleh media sehingga terbaca oleh masyarakat luas bahwa yang bersangkutan sangat dekat dengan Guru Sekumpul. Orang bisa saja memanfaatkan popularitas seseorang dalam kepentingankepentingan untuk tujuan tertentu. K.H. Muhammad Zaini Abdul Ghani adalah seorang ulama yang menjadi panutan umat, seorang ulama karismatik. Suaranya didengar, perkataannya diikuti, sehingga banyak orang yang memanfaatkan untuk tujuan politik.

Contoh lainnya ada beberapa ulama di Kalimantan Selatan yang selalu dikunjungi dan diminta nasehat misalnya K. H. Juhdi Banjarmasin, K. H. Asmuni (Guru Danau), K. H. Bakhit (Barabai). Ketika sedang dalam pengajian, para elite politik ini ikut hadir bersama masyarakat dalam acara pengajian rutin yang dilaksanakan oleh para ulama tersebut. Di Kalimantan Selatan bagi para elite politik, ketika mencalonkan diri sebagai pemimpin daerah selalu mendekati para ulama.

Dalam perspektif agama, hal ini disebut moralitas politik elite agama. Pola hubungan otoritas elite agama (tuan guru) menjadi penjaga moral dan intelektual. Politik dimaknai bagaimana mengalokasikan sejumlah nilai secara otoritatif bagi masyarakat.

Dalam kehidupan sehari-hari terdapat sejumlah nilai yang selalu dicari, dikejar-kejar dan tentu saja dipertaruhkan orang dalam hidup bermasyarakat serta bernegara. Nilai-nilai tersebut sangat berharga dan bermakna dalam kehidupan sehingga orang dapat melakukan apa saja untuk memperolehnya. Nilai-nilai tersebut adalah kekuasaan, kekayaan, kehormatan, kesehatan, kesejahteraan, kebebasan, keamanan, dan lain-lain.

Dalam mengalokasikan sejumlah nilai tersebut di atas, kendatipun orang dapat melakukan apa saja untuk memperolehnya, namun elit agama meletakkan koridor etis untuk mencapai nilai-nilai tersebut. Elite agama menunjukkan sikap yang tegas terhadap korupsi, mengajak masyarakat untuk memerangi ketidakadilan, menghimbau pemerintah untuk terus menggelindingkan proses demokrasi dan keterbukaan, maka ia dapat disebut sedang menjalankan high politics. Moralitas politik terletak pada gerakan amar ma'ruf nahi mungkar berarti ia telah melakukan politik yang luhur. ${ }^{25}$

Menurut Imam Suprayogo bahwa elite agama (kyai, ulama, tuan guru) sebagai pemimpin yang memerlukan otoritas, dan terlibat dalam peran-peran sosial untuk kepentingan masyarakat. Istilah terlibat menggambarkan bahwa kyai sesungguhnya tidak aktif dan tidak sengaja ikut mengambil bagian, akan tetapi karena posisinya sebagai pihak yang memiliki pengaruh, maka dilibatkan atau dimanfaatkan oleh pihak-pihak tertentu untuk mendapatkan keuntungan politik. ${ }^{26}$

Di Kalimantan Selatan Pemilihan Umum 2014 terlibat secara langsung beberapa ulama dan terpilih sebagai anggota DPRD provinsi Kalimantan Selatana yaitu Drs. K.H. Asnawi, SH (Partai Persatuan Pembangunan), Habib Ali Khaidir Alkaff (Partai Persatuan Pembangunan),K.H. M. Husni

${ }^{25}$ Lihat Musafir Pababbari, Islam dan Politik Lokal Studi Sosiologis atas Tarekat Qadiriyah di Mandar (Makassar: Padat Daya, 2009), 32-33.

26Imam Suprayogo, Kyai dan Politik. Membaca Citra Politik Kyai, h. 45-46. 
Nurin (Partai Kebangkitan Bangsa). Mereka terlibat secara langsung sebagai figur ulama dalam ranah keperintahan daerah Provinsi Kalimantan Selatan (legislatif). ${ }^{27}$

Ketika pemilihan kepala daerah, para calon mengemukakan visi dan misinya selalu mencantumkan program-program yang berkaitan dengan agama. Contohnya ketika pemilihan kepala daerah tahun 2010 ada beberapa pasang calon gubernur dan wakil Gubernur Provinsi Kalimantan Selatan. Pasangan calon H. Khairil Wahyuni, SH, MBA dan Drs. H. Alwi Sahlan M.Sc mencantumkan visinya yang berkaitan dengan agama, "Memasyarakatkan dan membina pengembangan nilai-nilai keagamaan dalam kehidupan sosial budaya masyarakat". Pasangan calon Drs. H. Rudy Arifin MM dan Drs. H. Rudy Resnawan mencantumkan visinya "Meningkatkan kualitas kehidupan beragama, sosial dan budaya". Pasangan H. M. Rosehan NB, SH dan Drs. H. Saiful Rasyid MM mencantumkan misinya "menjadikan Kalimantan Selatan maju dalam bidang seni, budaya, olahraga dan meningkatkan religiusitas masyarakat agar daerah ini menjadi provinsi yang baldatun thayyibatun wa rabbun ghafur". Pasangan calon dr. H. M. Zairullah Azhar, M.Sc dan Habib Abu Bakar Al-Habsyi mencantumkan misi "Meningkatkan keunggulan modal sosial, kultural, dan modal spiritual demi terwujudnya kohesi dan kepedulian sosial, serta terbangunnya etos kerja unggul berbasis nilainilai sosial budaya lokal dan terbentuknya komunitas-komunitas ilahiyah di tengah kemajuan fisik dan ekonomi yang makin pesat". ${ }^{28}$

Fenomena spesifik di Kalimantan Selatan didasarkan kepada suatu analisis politik bahwa masyarakat Kalimantan Selatan dikenal sebagai komunitas yang memiliki latar belakang kultur religius yang sangat tinggi. Bagi masyarakat fenomena Habaib/Habib, memiliki hubungan pertalian dengan Nabi Muhammad Saw., sehingga dalam pandangan masyarakat mereka para Habaib mendapat tempat khusus dalam strata sosial. Faktor adanya pertalian Habaib ini sehingga selalu didukung oleh masyarakat. ${ }^{29}$ Tercatat beberapa nama yang terpilih ketika pemilihan umum yaitu Habib Abu Bakar Al-Habsyi (DPR RI), Habib Ali Khaidir Alkaff (DPRD Provinsi Kalimantan Selatan), Habib Abdulhamid Al-Bahasyim (DPD RI), Habib Abdurrahman Al-Bahasim yang pupoler dengan sebutan Habib Banua (DPD RI), Habib Said Hasan Al-Habsyi, BSc. (DPRD Prov. Kal-Sel.)

Dalam menyongsong pemilihan kepala daerah terutama pemilihan Gubernur dan Wakil Gubernur Provinsi Kalimantan Selatan yang akan dilaksanakan pada tanggal 9 Desember 2015 nanti, para pasangan calon mencantumkan visi dan misi sebagai berikut:

Pasangan calon dr. H. M. Zairullah Azhar, M.Sc dan Dr. H. Muhammad Sapi'i, M.Si mencantumkan misi "Meningkatkan keunggulan modal sosial, kultural dan modal spiritual demi terwujudnya kohesi dan kepedulian sosial, serta terbangunnya etos kerja unggul berbasis nilai-nilai sosial dan budaya lokal dan terbentuknya komunitas-komunitas ilahiyah ditengah kemajuan fisik dan ekonomi yang makin pesat".

Pasangan calon H. Sahbirin Noor, S.Sos, MH dan Drs. H. Rudy Resnawan mencantumkan misi "Mengembangkan sumber daya manusia yang agamis sehat, cerdas dan terampil".

Pasangan calon H. Muhiddin dan H. Gusti Farid Hasan Aman mencantumkan misi "Meningkatkan kualitas hidup masyarakat melalui pendidikan. Kesehatan dan kualitas sumber daya manusia yang maju, dan religius, meningkatkan daya saing ekonomi rakyat yang berbasis ekonomi kreatif, agro industri dan pengembangan produk unggulan daerah".

${ }^{27}$ Laporan Penetapan Perolehan Suara dan Kursi Partai Politik serta Penetapan Calon Terpilih Anggota DPRD Provinsi Kalsel Tahun 2014, KPU Provinsi Kalimantan Selatan.

${ }^{28}$ KPU Provinsi Kal-Sel, Laporan Penyelenggaraan Pemilu Kepala daerah dan Wakil Kepala Daerah Provinsi Kalimantan Selatan Tabun 2010 (Banjarmasin: KPU Kal-Sel, 2010), 191-195.

${ }^{29}$ Mohammad Effendy, Upaya Membangun Demokrasi Lokal (Banjarmasin: PT. Grafika Wangi Kalimantan, 2006), 
Pejabat Gubernur Provinsi Kalimantan Selatan Ir. Tarmizi A. Karim M. Sc dalam iklan pemilu kepala daerah tahun 2015 mencantumkan tema "Sukseskan pemilihan Gubernur dan Wakil Gubernur Kalimantan Selatan, Bupati dan Wakil Bupati, Walikota dan Wakil Walikota di Kalimantan Selatan tanggal 9 Desember 2015, memilih pemimpin adalah ibadah:

1. Datanglah ke TPS dan gunakan hak pilih.

2. Pelihara kerukunan dan hindari permusuhan.

3. Suara anda adalah masa depan Kal-Sel.

4. Hindari politik uang karena merendahkan martabat kemanusiaan. ${ }^{30}$

Fenomema sosial yang menarik, juga ketika mengamati peristiwa menghubungkan Agama dan politik, agama menjadi landasan berpijak dalam setiap langkah. Peringatan Milad Kesultanan Banjar ke-511 yang dipimpin oleh Sultan Kesultanan Banjar Sultan Ir. H. Khairul Saleh MM dengan tema "Agama ditegakkan, adat diteguhkan dan rakyat dirakatkan". Tema ini merupakan rangkaian dari tema-tema milad sebelumnya yang sarat makna dan kearifan budaya. Agama ditegakkan memiliki makna bahwa di atas ururan apapun agama harus tetap menjadi pondasi dan pegangan. Adat diteguhkan, memiliki makna adat istiadat dan budaya yang bertiang pondasi agama terus diteguhkan. Dengan landasan agama amalan adat istiadat dan budaya selaras dengan rakyat Banjar. Rakyat banua Banjar dirakatkan yaitu rakyat tidak boleh terpecah karena urusan dunia, perbedaan untuk semua, merangkul yang berbeda, berbuat baik antar sesame. Jika agama ditegakkan niscaya iman akan tertanam. ${ }^{31}$

Dengan demikian dapat dikatakan bahwa politik dan agama sangat berkaitan sangat erat. Agama diperlukan sebagai sistem keyakinan, sistem makna yang terwujud dalam kehidupan sosial, melalui interaksi yang responsif terhadap situasi-situasi yang dihadapi oleh para penganutnya. Sistem nilai suatu agama mempengaruhi pemikiran dan tingkah laku, penyesuaian lembaga-lembaga keagamaan dengan lembaga-lembaga sosial lainnya. Agama membantu mendorong terciptanya sistemsistem nilai sosial yang terpadu dan utuh. ${ }^{32}$

Pemenang pemilukada tahun 2010 adalah pasangan Drs. H. Rudy Arifin MM dan Drs. H. Rudy Resnawan. Program keagamaan yang telah dicantumkan dalam visi dan misi dijabarkan dalam beberapa item program:

1. Program peningkatan kehidupan umat beragama.

2. Menciptakan kerukunan umat beragama.

3. Pengamalam agama dalam kehidupan masyarakat.

4. Program pendidikan al-Qur'an di Kalimantan Selatan

5. Koordinasi pimpinan keagamaan di Provinsi Kalimantan Selatan

6. Memberi bantuan dana APBD kepada organisasi keagamaan terutama MUI dan majelis agama lainnya. ${ }^{33}$

${ }^{30}$ http:/ /www.kalselprov.go.id

${ }^{31}$ Redaktur, Milad Kesultanan Banjar ke 511 Wujud Komitmen dan Konsistensi Kesultanan Banjar, Banjarmasin Post, Sabtu, 31 Oktober 2015.

32 Abdul Azis Thaba, Islam dan Negara dalam Politik Orde Baru (Jakarta: Gema Insani Press, 1996), 35.

${ }^{33}$ M. Nasir, Pegawai Pemprov Kal-Sel bagian Kesra, wawancara pribadi tanggal 31 Oktober 2015. 


\section{Hubungan Agama dan Politik}

Hubungan politik dengan agama tidak dapat dipisahkan. Dapat dikatakan bahwa politik berbuah dari hasil pemikiran agama agar tercipta kehidupan yang harmonis dan tentram dalam kehidupan berbangsa dan bernegara. Hal ini disebabkan, pertama, oleh sikap dan keyakinan bahwa seluruh aktifitas manusia, tidak terkecuali politik, harus dijiwai oleh ajaran-ajaran agama; kedua, disebabkan oleh fakta bahwa kegiatan manusia yang paling banyak membutuhkan legitimasi adalah bidang politik, dan hanya agamalah yang dipercayai mampu memberikan legitimasi yang paling meyakinkan karena sifat dan sumbernya yang transenden.

Agama secara hakiki berhubungan dengan politik. Kepercayaan agama dapat mempengaruhi hukum, perbuatan yang oleh rakyat dianggap dosa, seperti sodomi dan incest. Seringakali agamalah yang memberi legitimasi kepada pemerintahan. Agama sangat melekat dalam kehidupan rakyat dalam masyarakat industri maupun nonindustri, sehingga kehadirannya tidak mungkin tidak terasa di bidang politik. Sedikit atau banyak, sejumlah pemerintahan di seluruh dunia menggunakan agama untuk memberi legitimasi pada kekuasaan politik.

Di dalam sejarah Islam, masuknya faktor agama (teologi) ke dalam politik muncul ke permukaan dengan jelas menjelang berdirinya dinasti Umayyah. Hal ini terjadi sejak perang Siffin pada tahun 657, suatu perang saudara yang melibatkan khalifah 'Ali bin Abi Talib dan pasukannya melawan Mu'awiyah bin Abi Sufyan, Gubernur Syria yang mempunyai hubungan keluarga dengan 'Utsman, bersama dengan tentaranya. Peristiwa ini kemudian melahirkan tiga golongan umat Islam, yang masing-masing dikenal dengan nama Khawarij, Syi'ah, dan Sunni. ${ }^{34}$

\section{Penutup}

Dari pemaparan di atas dapatlah dilihat bahwa agama dan politik saling memiliki keterkaitan. Agama merupakan sesuatu yang sangat penting untuk memberikan legitimasi terhadap kekuasaan ataupun persoalan politik. Demikian pula halnya, di Kalimantan Selatan, semenjak Zaman Kerajaan Banjar seorang raja menjadikan agama sebagai pandangan dan pedoman dalam menjalankan pemerintahan. Dalam pemerintahan, ulama menempati peran penting sebagai pemimpin nonformal yang memberikan nasehat dan fatwa. Bahkan dalam event politik, seperti Pilkada di tingkat propinsi ataupun kabupaten nuansa keagamaan juga menjadi slogan dalam kampanye politik. Yang terpenting adalah bagaimana agama benar-benar menjadi pedoman pemerintah dan rakyat dalam menjalankan aktivitas politik dan sosial kemasyarakatan, bukan semata-mata untuk mendapatkan kekuasaan []

\section{DAFTAR PUSTAKA}

Bennet, John R. "Religion" dalam Encyclopedia Americana. Vol. 23. New York: American Corporation, 1977.

Departemen Pendidikan dan Kebudayaan. Kamus Besar Bahasa Indonesia. Jakarta: Balai Pustaka. 1995.

Effendy, Mohammad. Upaya Membangun Demokrasi Lokal. Banjarmasin: PT. Grafika Wangi

Kalimantan. 2006.

${ }^{34}$ http://akank-sutha.blogspot.co.id/2012/04/hubungan-politik-dan-agama.html, diakses tanggal 1 November 
Hakim, Abdul. Syair-Syair yang Berisi Pujian kepada Al-Mukarraom Al'Alim Al'Allamah Syekh Muhammad Zaini Sekumpul Martapura. Martapura: Prc. Putra Sahara.Comp. t.th.

http://akank-sutha.blogspot.co.id/2012/04/hubungan-politik-dan-agama.html, diakses tanggal 1 November 2015.

http://www.kalselprov.go.id

Jamalie, Zulfa. "Sultan Banjar yang Mencintai dan Dicintai", dalam Berkelana Mencari Sultan Banua Banjar. Banjarmasin: Pustaka Banua.

Kahmad, Dadang Sosiologi Agama. Bandung: Remaja Rosdakarya. 2000. Cet. I.

KPU Provinsi Kal-Sel. Laporan Penyelenggaraan Pemilu Kepala Daerah dan Wakil Kepala Daerah Provinsi Kalimantan Selatan tabun 2010. Banjarmasin: KPU Kal-Sel. 2010.

Mubaraq, Zulfi. Sosiologi Agama. Malang: UIN-Maliki Press. 2010. Cet. I.

Mujib, Abdul. Kepribadian dalam Psikologi Islam. Jakarta: PT RajaGrafindo Persada. 2007.

Munawwir, Ahmad Warson. Kamus al-Munawwir Arab-Indonesia Terlengkap. Surabaya: Pustaka Progressif. 1997. Cet. II.

Nasution, Harun. Islam Ditinjau dari Berbagai Aspeknya. Jilid I. Jakarta: Universitas Indonesia Press. 1985.

Newman, William M. The Social Meaning of Religion. Chicago: Rand Mcnally College Publishing Company. 1974.

Pababbari, Musafir. Islam dan Politik Lokal Studi Sosiologis atas Tarekat Qadiriyah di Mandar. Makassar: Padat Daya. 2009.

Redaktur, "Belum Ada Tandingannya", Banjarmasin Post, Kamis, 11 Agustus 2005

Redaktur, "Kesan Mereka Terhadap Guru Sekumpul”, Banjarmasin Post, Kamis, 11 Agustus 2005.

Redaktur, "Milad Kesultanan Banjar ke 511 Wujud Komitmen dan Konsistensi Kesultanan Banjar", Banjarmasin Post, Sabtu 31 Oktober 2015.

Rosyadi, Ahmad. Bertamu ke Sekumpul, Yokyakarta: PT. LkiS Pelangi Aksara. 2004. Cet. III.

Suprayogo, Imam. Kyai dan Politik. Membaca Citra Politik Kyai. Malang: UIN Malang Press. 2009.

Thaba, Abdul Azis. Islam dan Negara dalam Politik Orde Baru. Jakarta: Gema Insani Press. 1996.

Wach, Joachim. Sociology of Religion. London: The University of Chicago Press. L.td. 1971.

Webster, Noah and Jean L. McKehnie. Webster's New Universal Unabridged Dictionary. New York: New World Dictionary/Simon and Schuser. 1979. 